\title{
In vitro culture and characterization of the HSP70 gene on Vanda tricolor Lindley var. Suavis 'Queen Maxima'
}

\author{
Endang Semiarti ${ }^{*}$, Naufal Ghozi Adityal Perdana ${ }^{1}$, Rozikin Rozikin ${ }^{1}$ and Febri Yuda Kurniawan ${ }^{2}$ \\ ${ }^{1}$ Department of Tropical Biology, Faculty of Biology, Universitas Gadjah Mada, Sleman 55281, Yogyakarta, Indonesia \\ ${ }^{2}$ Study Program of Biotechnology, Postgraduate School, Universitas Gadjah Mada, Sleman 55281, Yogyakarta, Indonesia
}

\begin{abstract}
Vanda tricolor Lindey var. Suavis is an endemic orchid from Mt.Merapi, Yogyakarta Special Region, Indonesia. This orchid has beautiful flowers with unique patterns of white and purple spots, fragrant and can live in the slopes of Mt.Merapi which is a very active volcano. UGM in collaboration with the Netherlands carried out ex situ conservation of the $V$. tricolor Merapi through the self-pollination of orchids by the Queen of the Netherlands, Queen Maxima on March 11, 2020 at the UGM campus, Yogyakarta. In honor, the new generation of crosses is named Vanda tricolor var Suavis 'Queen Maxima'. This study aims to produce mass quantities of the orchid and characterize the HSP70 gene in it. Methods: Standard in vitro culture for Vanda on MS, NP and VW medium, isolation of plant gDNA, PCR with V. tricolor HSP70primers and sequencing of amplicon DNA. The results showed that $>90 \%$ of $V$. tricolor 'Queen Maxima' seeds germinated well in all media and the best on VW medium. $V$. tricolor has the HSP70 protein with PTZ00009 super family amino acid motif that $87 \%$ similar to the HSP70 protein from the Phalaenopsis equestris orchid, which is probably the reason $V$. tricolor become superior to high temperature environments.
\end{abstract}

Keywords: Ex-situ conservation, HSP70, Mount Merapi, Vanda tricolor var Suavis 'Queen Maxima',

\section{Introduction}

Use Orchids (Orchidaceae) are flowering plants with the largest number of members about 26972 species [1]. Indonesia is one of the countries contributing to the diversity of orchids in the world, with around 5000 species in Indonesia [2]. Moreover, orchids are ornamental plants with high commercial value [3]. One species of orchid that has high potential to be developed is Vanda tricolor Lindley var. Suavis which mostly grows on the slope of Mount Merapi and its surroundings [4]. V. tricolor has unique characters in its perianthium with a white base color and red to purplishred spots, purple labellum and a distinctive aroma [5]. In addition, $V$. tricolor has been reported to have a special character in the HSP70 gene structure. Heatshock proteins (HSPs) are ubiquitous proteins with important roles in response to biotic and abiotic stress. The 70-kDa heat-shock genes (HSP70s) encode a group of conserved chaperone proteins that play central roles in cellular networks of molecular chaperones and folding catalysts across all the studied organisms including bacteria, plants and animals [6]. Several HSP70s involved in drought tolerance have been well characterized in various plants. The HSP70 gene is responsible for high temperature resistance [7]

The existence of large scale exploitation and natural habitat destruction of $V$. tricolor has caused its population to decline [8]. Conservation efforts are needed to overcome this problem, both in situ and ex situ. Maintain of seeds supply is an important factor in orchid conservation [9]. Orchid seeds have a disadvantage, because the seeds do not have food reserves. Micropropagation or in vitro propagation of this orchid will become an effective method, because the time required is relatively short and seeds produced are large and uniform [10].

On March 11, 2020, at Universitas Gadjah Mada (UGM) Campus Senate Hall, V. tricolor var. Suavis Lindley was pollinated with self-pollination by Queen Maxima from The Netherlands Kingdom. Queen who was come with King Willem Alexander was given the honor to pollinate orchid for the purpose of conserving the endemic orchid of Merapi $V$. tricolor and building friendship between Dutch government, Dutch scientists with Indonesian government and scientists. From this pollination, three orchid siliques have been successfully obtained which are ready to be nurtured to form fertile seeds that will be planted for conservation of the original Merapi orchid $V$. tricolor. The hybrid plant itself has been given a scientific name: Vanda tricolor Lindley var. Suavis 'Queen Maxima' in honor of the Queen from Netherlands. Therefore, it is necessary to carry out research to maintain and optimize the propagation technique of $V$. tricolor 'Queen Maxima' both in vivo and in vitro. In addition, it also needs to be completed with morphological and molecular character data,

\footnotetext{
*Corresponding author: endsemi@ugm.ac.id
} 
especially the $H S P 70$ gene structure in the $V$. tricolor 'Queen Maxima'.

Orchid propagation with in vitro culture has been widely practiced both in the world and in Indonesia, such as Dendrobium nanum [11], Phalaenopsis amabilis [12], Dendrobium phalaenopsis [13], and Grammatophyllum scriptum [14]. It is expected that seedlings of $V$. tricolor 'Queen Maxima' can grow well both in vitro and ex vitro. Information regarding the morphological characters of $V$. tricolor 'Queen Maxima' will be complemented with its molecular characters, especially regarding the structure of the HSP70 gene which is characteristic of $V$. tricolor var suavis which is very heat resistant in its natural habitat, Mt. Merapi. This study aims to determine the morphological and molecular characters of $V$. tricolor var Suavis, especially the character of the HSP70 gene in these plants. In addition, this study also aims to determine the percentage of germination and growth of $V$. tricolor 'Queen Maxima' orchid embryos that have been grown in vitro.

\section{Materials and methods}

\subsection{Plant materials}

The mother plant of the $V$. tricolor var Suavis orchid used was obtained from Mrs. Uminurida from the Indonesian Orchid Society, Yogyakarta Special Region Province. Morphological observations included habitus, morphology of vegetative and generative organs. $V$. tricolor pollination begins with selecting flowers that are ready for pollination (four days old after fully blooming). Then pollen is taken using a toothpick and inserted into stigma cavity. Pollination was carried out by self-pollination on $V$. tricolor by Queen Maxima. Observations of pollination results include the length of flower stalks, ovaries, color of flower stalks and flowers. Color for every observed character was compared to $6^{\text {th }}$ edition Royal Horticulture Society (RHS) color chart [15].

\subsection{In vitro propagation of $V$. tricolor 'Queen Maxima'}

In vitro propagation begins with siliques/fruits presterilization by washing it with liquid soap and rinsing it with clean water. Then the siliques are sterilized by dipping the fruit in $70 \%$ alcohol and spreading it over a bunsen fire. The sterile silique is then cut longitudinally and transversally, so that the seeds can be taken with tweezers. Seeds are sown on Vacin and Went (VW), New Phalaenopsis (NP) and Murashige and Skoog (MS) medium in the bottle. Culture bottles were labelled and stored in the incubator room under a continuous white light of 1000 lux at a temperature of $25{ }^{\circ} \mathrm{C}$ for four weeks observation.

\subsection{Genome DNA isolation from V. tricolor}

For molecular characterization of HSP70 gene, five samples of $V$. tricolor aged seven years were used which were grown at Faculty of Biology, UGM. Sample number one is parent plant used in the self-pollination of $V$. tricolor to produce $V$. tricolor 'Queen Maxima', while other four samples are plants reproduced by Laboratory of Biotechnology, Faculty of Biology, UGM. Sample used was $V$. tricolor leaves taken on leaf number three from the shoot. Isolation of genomic DNA from orchids following method of [16] by placing 100 $\mu \mathrm{L}$ of $3 \% \mathrm{CTAB}$ solution into a $1.5 \mathrm{~mL}$ tube, then $\pm 300 \mathrm{mg}$ of plant material was cut about $0.5 \mathrm{~cm}^{2}$ and put into a tube containing $100 \mu \mathrm{L}$ of $3 \% \mathrm{CTAB}$ and then crushed using a small pestle. After the leaf samples were crushed, $400 \mu \mathrm{L}$ of CTAB was added. The solution was mixed until it was homogeneous, then the tubes were incubated in a water bath at a temperature of $55^{\circ} \mathrm{C}$ to $65^{\circ} \mathrm{C}$ for $30 \mathrm{~min}$. Tube was added with $500 \mu \mathrm{L}$ of chloroform then tube was shaken for $30 \mathrm{~min}$ at $100 \mathrm{rpm}$ at room temperature. Tube is opened and closed to remove the gas then closed again. Tubes were centrifuged at $5000 \mathrm{rpm}$ for $5 \mathrm{~min}$ at room temperature. Supernatant in the form of a clear layer $(300 \mu \mathrm{L}$ to $400 \mu \mathrm{L}$ ) was transferred to a new $1.5 \mathrm{~mL}$ tube. To the tube is added isopropanol in a ratio of $1: 1$ with the clear solution mentioned above or as much as $300 \mu \mathrm{L}$ to $400 \mu \mathrm{L}$. DNA solution tube is mixed until it is homogeneous by turning the tube back and forth 6 times then leaving it for $10 \mathrm{~min}$. Furthermore, the tubes were centrifuged at $5000 \mathrm{rpm}$ for $5 \mathrm{~min}$ at room temperature. Supernatant was discarded then the DNA precipitate was washed using $70 \%$ alcohol as much as $100 \mu \mathrm{L}$ then centrifuged again at $5000 \mathrm{rpm}$ for $2 \mathrm{~min}$ at room temperature. Supernatant was removed then the DNA precipitate was dried for $30 \mathrm{~min}$ at room temperature. After the DNA precipitate was dry, $100 \mu \mathrm{L}$ of $10 \mathrm{~T} 0.1 \mathrm{E} \mathrm{pH} 7.6$ was added.

\subsection{Amplification of the HSP70 and Actin gene by using Polymerase Chain Reaction (PCR)}

Amplification of HSP70 gene fragment from V.tricolor genome, two degenerate primers of HSP70 were used [7], namely DegHSP70 F2 (5'-SCARG ARTTCAAGMGSAAG), DegHSP70R2 (5'TAVACCT GGATSAGSACRC), DegHSP70F3 (5'ATYCCSACCA AGAAGGAG), DegHSP70R3 (5'MGYTTAG TCSAC CTCCTC). Two primers amplify sequences with sizes $600 \mathrm{bp}$ to $680 \mathrm{bp}$. For internal control of the PCR reaction, Actin gene was used as internal control, Actin primers used were specific primers for Actin gene, i.e ACT4F (5'GTATTCCCTAGCATTGTTGGT ) and ACT4R (5'CAGAGTGAGAATACCTCGTTTG)[16] resulting in a size of 114 bp amplified DNA fragment. For amplification, $2 \mu \mathrm{l}$ of $V$. tricolor genomic DNA was prepared, then five PCR premix was made for each primer type. The composition required is Bioline PCR Kit $12.5 \mu 1$, Nuclease Free Water $8.5 \mu 1$, DegHSP70F Primer $10 \mu \mathrm{M} 1 \mu \mathrm{l}$, and DegHSP70R primer $10 \mu \mathrm{M} 1 \mu \mathrm{l}$. The genomic DNA sample is mixed with the above 
ingredients into a $0.2 \mathrm{~mL}$ tube. The tubes are homogenated and then spindown. Sample was then fed into a PCR machine (BOECO, UK) with a predenaturation temperature of $95{ }^{\circ} \mathrm{C}$ for $1 \mathrm{~min}$, denaturation of $95^{\circ} \mathrm{C}$ for $30 \mathrm{~s}$, annealing $49^{\circ} \mathrm{C}$ (HSP70) and $51{ }^{\circ} \mathrm{C}$ (Actin) for $30 \mathrm{~s}$, and elongation of $72{ }^{\circ} \mathrm{C}$ for $1 \mathrm{~min}$. Then there are $72{ }^{\circ} \mathrm{C}$ post-extension for $90 \mathrm{~s}$, and $4{ }^{\circ} \mathrm{C} 15 \mathrm{~min}$ for hold phase. The cycle was repeated 30 times.

\subsection{HSP70 and Actin visualization}

Visualization was carried out by using electrophoresis in $1.4 \%$ agarose by weighing $0.3 \mathrm{~g}$ agarose dissolved in $30 \mathrm{~mL}$ TE $1 \mathrm{x}$. Wait 1 minute then heat it with a hot plate until homogeneous. After heating, it was waited until the temperature was $\pm 60{ }^{\circ} \mathrm{C}$, then $5 \mu \mathrm{L}$ of Goodview dye was mixed and shaken until it was homogeneous. The solution is poured carefully into a mold that has been fitted with a comb to make a well. The solution is kept so that there are no bubbles and waits for agarose to solidify for about $30 \mathrm{~min}$. Comb was removed and agarose gel was transferred to the electrophoresis tank. Furthermore 1x TBE solution was poured into the tank until the well was filled. Then $3 \mu$ of DNA solution was poured in the gel well. DNA marker used as much as $3 \mu \mathrm{L}$ and $1 \mu \mathrm{L}$ of loading dye. Solution of DNA marker and loading dye is homogenized with a pipette by way of up and down then put into the well. Press the button to start electrophoresis, electric current is set to $50 \mathrm{~V}$ and according to $30 \mathrm{~min}$. After that, the gel is lifted and placed on a UV illuminator coated with plastic wrap. Gel was visualized using a UV lamp at a wavelength of $312 \mathrm{~nm}$. Visible DNA bands were photographed using a digital camera.

\subsection{Sequence analysis of $H S P 70$ gene}

Sequence Analysis of $V$. tricolor HSP70 gene was conducted using trimming and contigting PCR product DNA fragments as the results of forward and reverse primary sequencing using CLC genomic workbench 12 (Qiagen). Contig results then identified using BLASTX (https://blast.ncbi.nlm.nih.gov/) and identified its gene structure using NCBI conserved domains (ccd) (www.ncbi.nlm.nih.gov/Structure/cdd/). Amino acid alignment, testing models for phylogeny trees and making phylogeny trees using MEGAX [29;30]. HSP: 325 AA, gene structure: Heat shock $70 \mathrm{kDa}$ protein, Phylogeny tree arranged using Maximum Likelihood method and Dayoff matrix based model with 100 replications [31].

\section{Results and discussions}

Based on morphological observations on Vanda tricolor that used as self-pollinated parent of $V$. tricolor to produce $V$. tricolor 'Queen Maxima', $V$. tricolor has a perennial, epiphytic, monopodial herbaceous plant habits (Figure 1A). Adventitious roots are cylindrical in shape with thick velamen on the root surface, aerial and dorsiventral root type. Stem is elongated flat, has nodes and internodes. Leaves are ribbon-type (ligulate), flat leaf edges (integer), asymmetrical incised leaf tips. Young leaves are duplicative and arranged alternately (distichous). Inflorescentia type pleurant, bunch (raceme), flowers arranged alternately (distichous) with 6 to 10 flowers. Flowers fragrant, basic color of flowers is white NN155B with moderate red dots $185 \mathrm{~B}$ (Figure 1B). Lips (labellum) consist of three lobes. Lip base is widened to side and moderate red $185 \mathrm{~B}$ in color. Center is moderate red 185B. Tip is dark purplish pink 186C and bends downward. Lip tip is split in half. Fruit is oval, strong yellow green 143B and has six ribs (Figure $1 \mathrm{C})$. Seeds are orange brownish 165B, microscopic and millions in number (Figure 1D-E). Morphological characters possessed by $V$. tricolor are in accordance with the descriptions mentioned in literature [4].

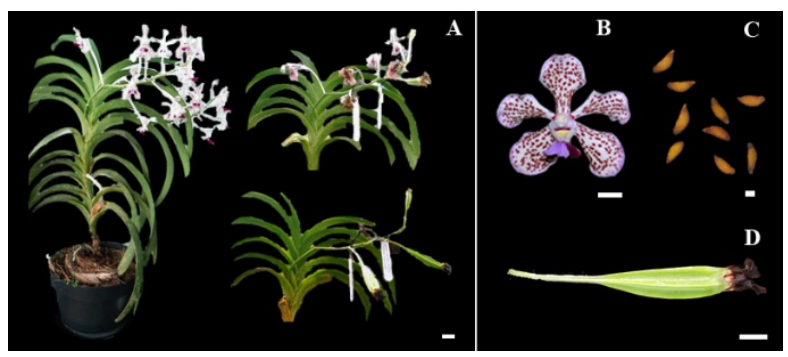

Fig. 1. Morphological characteristics of Vanda tricolor. (A) Habits, (B) Flower, (C) Fruit, (D) Ripe fruit with seed, (E) Seed. Bars: $1 \mathrm{~cm}(\mathrm{~A}, \mathrm{~B}, \mathrm{D})$ and $100 \mu \mathrm{m}(\mathrm{C})$.

Pollination on $V$. tricolor flowers was carried out on 11 March 2020 by Queen Maxima. Pollination is done by self-pollination. After pollination is carried out, post pollination observations has been done with morphological changes observation that occur until the fruit is formed and ready to be harvested. After pollination, 3 to 9 months later, fruit is ready to be harvested. Fruit ripeness of orchid depends on the type of orchid itself. For example in Dendrobium, fruit will ripen at the age of 3 to 4 months. Vanda, generally the fruit will ripen after 6 to 7 months. In Cattleya, fruit will ripen after 9 months. Orchid fruit is classified as a lantern fruits. This means that the fruit will break when ripe [18].

Observation of $V$. tricolor that was pollinated by Queen Maxima was carried out for $120 \mathrm{~d}$ (four months). After four months, the fruit is harvested and grown in vitro. Based on the results of post-pollination flower morphological observations on $V$. tricolor, it can be seen that there are differences including the size and color of flowers components. 
H-0
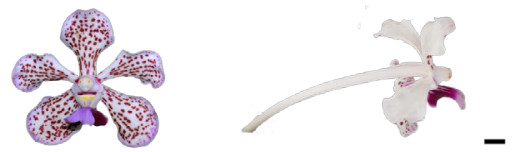

H-5
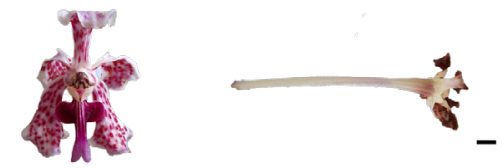

H-20

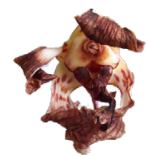

H-40
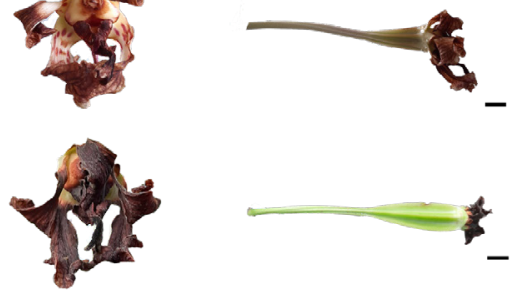

H-80
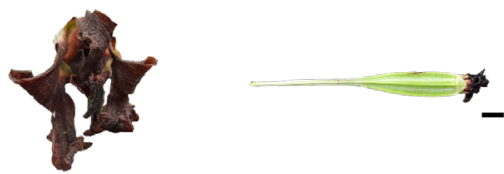

H-120
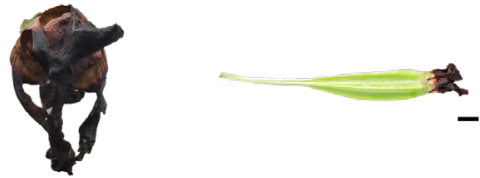

Fig. 2. Morphological characters of $V$. tricolor flowers after pollination. Bars: $1 \mathrm{~cm}$.

Before pollination (H-0), length of flower stalk reached $12 \mathrm{~cm}$ and ovarian zone had not been measured. Flower stalk are white NN155B and flowers are dominated by white NN155D. Five days after pollination (H-5), flower stalk shortened to $11 \mathrm{~cm}$ and ovarian zone was $1 \mathrm{~cm}$ long. Flower stalk and ovarian zone is white NN155B. Flower is dominated by moderate red 185B (Figure 2).

Twenty days after pollination $(\mathrm{H}-20)$, flower stalks shortened to $9.1 \mathrm{~cm}$ and ovarian zone increased in length by $2.9 \mathrm{~cm}$. Flower stalk and ovarian zone are pale yellow 165D. Flowers are drying up and dominated by orange brownish color $165 \mathrm{~B}$. Forty days after pollination (H40), flower stalks shortened to $7.8 \mathrm{~cm}$ and ovarian zone increased to $4.2 \mathrm{~cm}$ in length. Flower stalks and ovarian zone are brilliant yellow green color 142B. Flowers are dominated by strong brown color 172B (Figure 2).

Eighty days after pollination (H-80), length of ovarian zone $(5.8 \mathrm{~cm})$ was almost same as length of the flower stalk $(6.2 \mathrm{~cm})$. Flower stalks and ovarian zones are strong yellow green 143C. Flowers are strong brown 172B. Four months after pollination (H-120), flower stalks were shorter than the length of ovarian zone, namely, flower stalk was $5.7 \mathrm{~cm}$ and ovarian zone was $6.3 \mathrm{~cm}$. Flower stalks and ovarian zones are strong yellow green 143B. Flowers are strong brown 172B (Figure 2).

Morphological observations indicated that along with growth and development of the fruit that occurred after pollination was accompanied by morphological changes in the flowers. As the fruit grows towards maturity, flower perianthium will wither and dry more. When flower perianthium becomes dry, ovaries zone will get bigger and longer with age. After four months of observation, fruit is harvested. This age is relatively young when compared to literature which states that Vanda fruit ripens at the age of 6 to 7 months. Orchid fruit that will be planted in vitro should not be too old, because the fruit can be damaged during sterilization process and easily contaminate.

Orchid seeds from fruit that are too old have a low germination percentage. High content of phenolic compounds in seeds from old fruit is causing difficulty in germination process. According to [18], seeds in fruit that are too old accumulate tannins. Meanwhile, seeds from too young fruit take a relatively longer time to germinate. In addition, a low percentage of germination can be caused by immature embryos [19]. Based on a study [20], seeds from five month old $V$. tricolor fruits have the ability to develop into protocorms faster than seeds from seven month old fruits. Therefore, in this study seeds from fruit of $V$. tricolor which were four months old were used to see the viability and germination percentage of seeds (Figure 3 and Table 1).

In vitro propagation of $V$. tricolor 'Queen Maxima', in addition to strengthening the cooperative relationship between two countries, it also aims to conserve $V$. tricolor through ex situ and in situ conservation strategy. $V$. tricolor 'Queen Maxima' which has grown up will not only be reproduced for ex situ conservation, but this orchids will also be returned to their original habitat on Mount Merapi as an in situ conservation strategy.

Orchid seeds are very small with lengths ranging from $100 \mu \mathrm{m}$ to $200 \mu \mathrm{m}$, widths ranging from $200 \mu \mathrm{m}$ to $500 \mu \mathrm{m}$, weight ranges from $0.39 \mu \mathrm{g}$ to $3.6 \mu \mathrm{g}$ which are stored in orchid fruit with capsule form. $V$. tricolor are white when young (fruit 5 months or less than 6 months after pollination), yellow or brown when ready to sow (6 mon to 6.5 mon after pollination), and black if they are too old ( $>7$ mon) [5]. The best fruit for bottle orchid production is 6 to 6.5 months after pollination.

Sowing of orchid seeds in the laboratory requires nutrients that are packaged in a basic medium. It is known that there are several basic media commonly used, namely MS media (Murashige and Skoog) for micropropagation of orchids in general, NP (New Phalaenopsis) for micropropagation of the Phalaenopsis orchids genera, and VW (Vacin and Went) for micropropagation of orchids from Dendrobium genera [22]. In vitro propagation requires a growing medium that contains both macro and micro-nutrients that support plant growth and aseptic conditions [23]. The result of in vitro propagation is a uniform and virus-free plant [24].

Germination and developmental stages of the orchid seed begins with slowly breaking of testa which protects embryo. In orchid seeds that come from old fruit, the presence of this testa will be clearly visible. After testa is broken, white round embryo was able to seen. Embryo then develops into a protocorm which is round and yellow in color (Figure 3). Protocorm formation in $V$. tricolor orchids occurs two to four weeks after sowing [8]. Seed germination is characterized by imbibition of water by the tissues in the seeds so that the volume 
increases. Increased hydration of seed coat results in increased permeability to $\mathrm{O}_{2}$ and $\mathrm{CO}_{2}$. Swelling of seed causes seed coat to burst. Plants need at least three external factors before germination can occur, namely sufficient water, right temperature, sufficient oxygen and light.

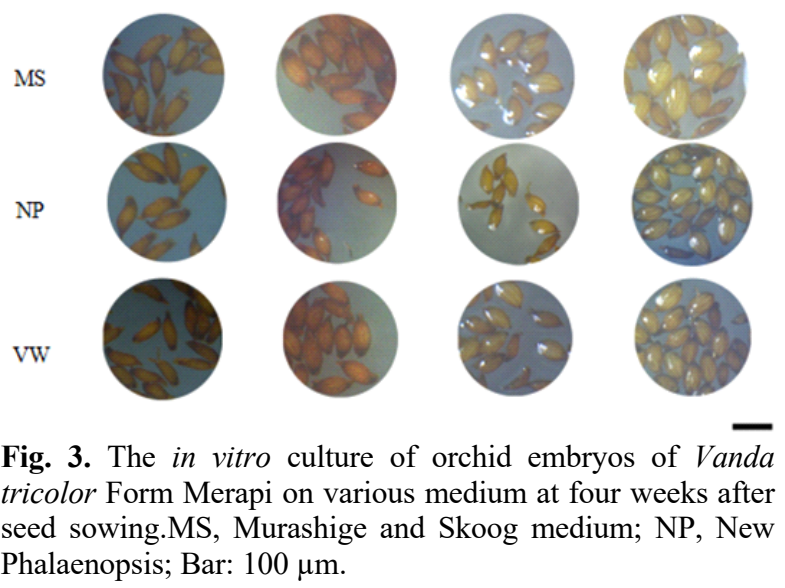

Table 1. Percentages of in vitro culture of Vanda tricolor orchid embryos on MS, NP, and VW media at 4 weeks after sowing.

\begin{tabular}{|c|c|c|c|c|c|}
\hline \multirow[b]{4}{*}{ Medium } & \multirow[b]{4}{*}{ Week } & \multicolumn{4}{|c|}{ Percentage $(\%)$} \\
\hline & & Stage & Stage & Stage & Stage \\
\hline & & 1 & 2 & 3 & 4 \\
\hline & & $\checkmark$ & $\downarrow$ & 0 & (1) \\
\hline \multirow[t]{4}{*}{ MS } & W-1 & 100 & 0 & 0 & 0 \\
\hline & W-2 & 72.05 & 27.95 & 0 & 0 \\
\hline & W-3 & 23.69 & 30.66 & 45.64 & 0 \\
\hline & W-4 & 3.04 & 8.23 & 17.58 & 71.14 \\
\hline \multirow[t]{4}{*}{ NP } & W-1 & 100 & 0 & 0 & 0 \\
\hline & W-2 & 76.97 & 23.03 & 0 & 0 \\
\hline & $\mathrm{W}-3$ & 18.19 & 34.11 & 47.70 & 0 \\
\hline & W-4 & 0.75 & 7.32 & 22.18 & 69.72 \\
\hline \multirow[t]{4}{*}{ VW } & $\mathrm{W}-1$ & 100 & 0 & 0 & 0 \\
\hline & W-2 & 76.11 & 23.89 & 0 & 0 \\
\hline & $\mathrm{W}-3$ & 17.57 & 45.61 & 36.82 & 0 \\
\hline & W-4 & 2.10 & 7.03 & 18.30 & 72.57 \\
\hline
\end{tabular}

Germination percentage of $V$. tricolor 'Queen Maxima' seeds in the three mediums showed the highest percentage of stage 4 was obtained in VW medium, then MS medium, and the lowest was in NP medium. (Figure 3 and Table 1). Level of seed viability is relatively good, because seeds have started the initiation of germination, although they have not germinated completely in $28 \mathrm{~d}$.

The VW medium is a very simple in vitro medium compared to other orchid mediums. The content of macronutrient elements only consists of sources of $\mathrm{N}$, namely (NH4) $2 \mathrm{SO} 4525 \mathrm{mg} / \mathrm{L}, \mathrm{KNO} 3500 \mathrm{mg} / \mathrm{L}$, MgSO4 7H2O $250 \mathrm{mg} / \mathrm{L}$, Ca3 (PO4) $200 \mathrm{mg} / \mathrm{L}$, KH2PO4 $250 \mathrm{mg}, \mathrm{Fe} 2$ (C4H4O6) 328 , and the micronutrient content of $\mathrm{MnSO} 4 \mathrm{H} 2 \mathrm{O} 7.5 \mathrm{mg}$. It turns out to be very appropriate for the growth of V.tricolor orchids. This is likely in accordance with the epiphytic way of life of V.tricolor attached to the host tree and can be in symbiosis with mycorrhizae for natural life [24]. Factors that influence the success of in vitro propagation include parent plants, types of explants, culture medium, types and concentrations of growth regulators, nitogens and carbon sources, and in vitro conditions [26].

Specialty of $V$. tricolor in dealing with environmental stress in the form of high temperatures is by having the Heat Shock Protein (HSP) gene. This HSP gene plays a role in maintaining cell homeostasis [7]. Apart from detecting the presence of HSP70 gene in $V$. tricolor with two degenerate primers types [7], the presence of Actin gene in $V$. tricolor was also carried out. Actin is a component of cytoskeleton which has vital functions and it expressed in all tissues [27]. Actin is used as an internal control because it is the most stable housekeeping gene.

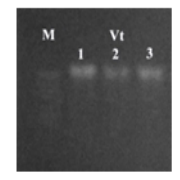

A.

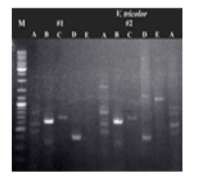

B

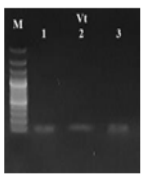

C
Fig. 4. PCR product of $H S P 70$ and $A C T I N$ genes in $V$. tricolor. M: Marker 100bp, VT1-5: number of sample, A: Actin (Primer ACTF4R4), B: HSP70 (Primer DegHSP70 F2R2), and C: HSP70 (Primer DegHSP70 F3R3).

In this study, three $V$. tricolor samples were used to detect of HSP70 gene in their genome to serve as superior parent for selfing purpose. Sample number 1 (VT 1) is $V$. tricolor which is the parent of $V$. tricolor 'Queen Maxima'. Based on the results of study, it could be seen that the three samples had amplified both the HSP70 gene and ACTIN gene (Figure 4). In the three samples, HSP70 gene was amplified by using DegHSP70 F2R2 and DegHSP70 F3R33 primers with length $600 \mathrm{bp}$ and $680 \mathrm{bp}$, respectively (Figure 4B), ACTIN gene can be amplified from all samples, which were indicated by the presence of a DNA band with length 114 bp (Figure 4C).

The evolutionary history was inferred by using the Maximum Likelihood method and Dayhoff matrix based model [29]. The bootstrap consensus tree inferred from 100 replicates [30] was taken to represent the evolutionary history of the taxa analyzed [31]. Branches corresponding to partitions reproduced in less than $50 \%$ bootstrap replicates were collapsed. The percentage of replicate trees in which the associated taxa clustered together in the bootstrap test (100 replicates) are shown next to the branches [31]. Initial tree(s) for the heuristic search were obtained automatically by applying Neighbor-Join and BioNJ algorithms to a matrix of pairwise distances estimated using a JTT model, and then selecting the topology with superior log likelihood value. A discrete Gamma distribution was used to model evolutionary rate differences among sites ( 5 categories $(+\mathrm{G}$, parameter $=0.1207))$. This analysis involved 15 amino acid sequences. There were a total of 325 positions in the final dataset. Evolutionary analyses were conducted in MEGA X [30].The amino acid analysis of the HSP70 protein of V.tricolor 'Queen Maxima' showed that the highly conserved amino acid motif in the HSP70 protein of V.tricolor is PTZ00009 
Superfamily motif(Figure 5A) and the phylogenetic tree showed that HSP70 protein of V.tricolor 'Queen Maxima has $87 \%$ similarity to HSP70 of P. equestris (Figure 5B). This is different from the findings of Semiarti and Rozikin [7] which show that HSP70 of V.tricolor Merapi was very different from other plants. including other orchids. The HSP70 sequence of $P$. equestris [34] which was taken from root, stem, leaf, flower buds, column, lip, petal, sepal and three developmental stages of seeds from a three-year-old plant has very similar structure to the HSP70 gene of V.tricolor. The similarity of the HSP70 protein structure in these two orchid species corresponds to the ability of these two plants as tropical epiphytic orchids to adapt to environmental factors, especially hot temperatures. This is also in accordance with Drini [36] that all eukaryotic genomes encode multiple members of the HSP70 family, which evolved distinctive structural and functional features in response to specific environmental constraints.

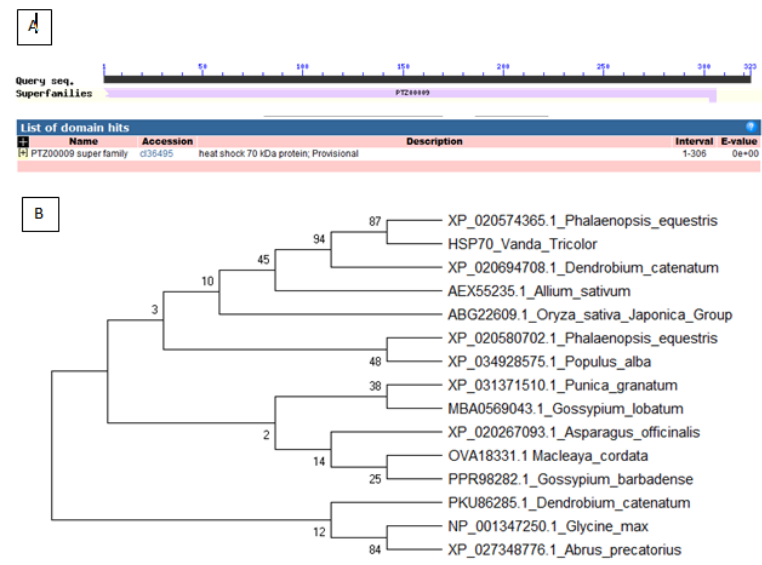

Fig. 5. Structure and Phylogenetic tree of HSP70 Protein in Vanda tricolor. (A) Amino acid structure contains PTZ00009 Superfamily conserved domain Accession $\alpha 36495$ heatshock $70 \mathrm{kDa}$, Provisional; (B) Phylogenetic tree of HSP70 Protein in $V$. tricolor shows $87 \%$ identity to HSP70 of Phalaenopsis equestris.

Beside that, the beautiful flowers of V.tricolor also have a unique aroma, due to the presence of phytochemicals of aromatic compounds in $V$. tricolor flowers such as fatty acid derivates, monoterpenoids, sesquiterpenoids, benzenoids, phenylpropanoids, hydrocarbons and other oxygenated compounds. These compounds are unique in $V$. tricolor [32]. The unique aroma produced in $V$. tricolor flowers potentially be used as raw material for aroma therapy in the field of pharmacology. Several compounds in Vanda also have pharmacological activities, including anti-inflammatory (imbricatin compounds; gigantol and methoxycoe lonin), anti-aging (vandateroside; eucomic acid; imbricatin; methoxycoe lonin; and gigantol), and antidepressants (phenol compounds). Phenanthrene compounds in Vanda have function as antioxidants, hepatoprotective and aphrodisiacs [35]. Based on these data, it can be ascertained that orchids from the Vanda genera, especially $V$. tricolor, have many benefits apart from a botanical aspect, therefore the efforts are needed to preserve these orchids. The right biotechnology application to do is mass propagation of $V$. tricolor both in vitro and ex vitro to conserve these orchids ex situ and in situ.

\section{Conclusion}

Based on in vitro seed germination data, it can be concluded that Vanda tricolor Lindley var. Suavis 'Queen Maxima' can thrive (>90\%) in all culture media and the best in VW media. $V$. tricolor has the HSP70 protein with the amino acid motif super family PTZ00009, which is $87 \%$ similar to the HSP70 protein from the Phalaenopsis equestris orchid, which supports $V$. tricolor to be superior to high temperature environments. This supports the conservation effort of $V$. tricolor plants both in situ and ex situ.

Authors would like to thank Ms. Uminurida (Indonesian Orchid Society, Yogyakarta Special Region Province) for providing the mother plant Vanda tricolor var Suavis form Merapi as the main plant material. The author also expresses gratitude to Faculty of Biology UGM for providing Research Grants for Lecturers and Students for Fiscal Year 2020 to ES with contract number: 1214/ UN1 / FBI.1 / KSA / PT.01.03 / 2020, 17 April 2020.

\section{References}

1. C.R. Metcalfe, W.L. Stern, Orchidaceae, Oxford University Press, Oxford, (2014), p. 122.

2. V.H. Heywood, P.W. Jackson, Tropical Botanic Gardens: Their Role in Conservation and Development, Academic Press, New York, (2012), p. 110.

3. F. Pangestu, S.A. Aziz, D. Sukma, J. Hort. Indonesia 5,1, 29-35 (2014)

4. J.B. Comber, Orchids of Java, Charoen Slip Press, Bangkok, (1990), p. 219.

5. R. Dwiyani, Anggrek Vanda tricolor var. Suavis Udayana University Press, Bali, (2014), p. 5-15.

6. J. Liu, R. Wang, W. Liu, H. Zhang, Y. Guo, R. Wen, Genes 2018,9, $35 \quad$ (2018). doi:10.3390/genes9020035

7. E. Semiarti, Rozikin, Karakterisasi gen ketahanan terhadap suhu tinggi HSP70 pada anggrek Vanda tricolor var. Suavis forma Merapi, in Proceedings of Seminar Nasional Masyarakat Biodiversitas Indonesia, SNMBI, March 2015, Indonesia (2015).

8. R. Dwiyani, A. Purwantoro, A. Indrianto, E. Semiarti, Jurnal Bumi Lestari 12,1, 93-95 (2012).

9. E. Raynalta, D. Sukma, Jurnal Hortikultura Indonesia 43, 131-139 (2015).

10. R.F. Lo, S.M. Nalawade, C.L. Kuo, C.L. Chen, H.S. Tsay, In Vitro Cell Dev. Biol. Plant, 40, 528-535 (2004).

11. M. Maridass, R. Mahesh, G. Raju, G. Benniamin, K. Muthuchelian, International Journal of Biological Technology 1,2, 50-54 (2010). 
12. W. Mose, A. Indrianto, A. Purwantoro, E. Semiarti, HAYATI J Biosci 24,4, 201-205 (2017)

13. A. Setiaji, N. Setiari, E. Semiarti, Proceedings of Seminar Nasional Masyarakat Biodiversitas Indonesia, SNMBI, June 2018, Indonesia (2018)

14. A.B. Sasongko, A. Fatumi and A. Indrianto, IJBiotech 21,2, 109-116 (2016)

15. RHS, Colour Chart $6^{\text {th }}$ ed. Royal Horticultural Society, United Kingdom, (2015).

16. E. Semiarti, Y. Ueno, H. Tsukaya, H. Iwakawa, C. Machida, Y. Machida, Development 128,10, 17711783 (2001).

17. X.Y. Yuan, S.H. Jiang, M.F. Wang, J. Ma, X.Y. Zhang, B. Cui, Appl Biochem Biotechnol 173,6, 115 (2014).

18. H. Iswanto, Petunjuk perawatan anggrek, Agromedia Pustaka, Jakarta, (2002).

19. J. Arditti, Fundamentals of orchid biology, John Wiley \& Sons, Inc, New York, (1991).

20. G.A. Venturieri and E.A.M. Arbieto, Maringa 33,3, 498-499 (2011).

21. R. Dwiyani, J. Hort. Indonesia 4,2, 90-93 (2013).

22. A.I.M. Saad, A.M. Elshahed, Plant tissue culture media, InTech, Winchester, (2012), p. 37-38.

23. W.G. Hopkins, N.P.A. Huner, Introduction to plant physiology $3^{\text {rd }}$ edition, John Wiley and Sons Inc., New York, (2004), p. 119.

24. T. Thiagarajan, H. Recinos, A. Tillett, Eur. Sci. 9,33, 357-362 (2013).

25. R. Latifah, T. Suhermiatin N. Ermawati, J. Appl. Agric. Sci. 1,1, 59-62 (2017).

26. G.I. Nic-Can, R.M. Galaz-Ávalos, C. De-la-Peña, A. Alcazar-Magaña, K. Wrobel, V.M. LoyolaVargas, PLoS ONE 10,6, 1-21 (2015).

27. D.I. Roslim, Herman, Jurnal Bioslogos 7,1, 9-16 (2017).

28. S. Hannum, K. Akashi, U.W. Suharsono, A. Hartana, A. Yokota, Suharsono, Makara Sains 14,2, 163-167 (2010).

29. R. Schwarz, M. Dayhoff. Matrices for detecting distant relationships. In Dayhoff M., editor, Atlas of protein sequences, National Biomedical Research Foundation (1979).

30. S. Kumar, G. Stecher, M. Li, C. Knyaz, K. Tamura, Molecular Biology and Evolution 35, 1547-1549 (2018).

31. J. Felsenstein, Evolution 39, 783-791 (1985).

32. S. Darmasiwi, V. Indriani, D. Innata, E. Semiarti, The potential production of aromatic compounds in flowers of Vanda tricolor, in AIP Conference Proceedings, ICMNS, 2-3 November 2014, Bandung, Indonesia (2015)

33. E. Semiarti, A. Purwantoro, I.P. Sari, Orchids Phytochemistry, Biology and Horticulture, Reference Series in Phytochemistry, Springer, Cham, (2020), p. 1-14.
34. N. Ferradini, R. Iannacone, S. Capomaccio, A. Metelli, N. Armentano, L. Semeraro, et al.

PLoS ONE 10,5: e0126051 (2015). https://doi.org/10.1371/journal.pone.0126051

35. S-C. Niu, Q.Xu, G-Q Zhang, Y-Zhang, W-C Tsai,JL Hsu, C-K Liang, Y-B Luo, Z-J Liu, Phalaenopsis equestris. 3, $160083 \quad$ (2016). DOI: 10.1038/sdata.2016.83

36. S. Drini, A. Criscuolo, P. Lechat, H. Imamura, T. Skalický, N. Rachidi, J.Lukeš, J-C Dujardin, G. F. Genome Biology and Evolution, 8,6, 1980-1995 (2016). https://doi.org/10.1093/gbe/evw140 